\title{
Organ Measurement Result Standard Unit
}

National Cancer Institute

\section{Source}

National Cancer Institute. Organ Measurement Result Standard Unit. NCI Thesaurus.

Code C119899.

The standard unit of measure for the organ measurement results. 